\title{
EVOLUTIONARY DIFFUSION: INTERNAL AND
EXTERNAL METHODS USED TO ACQUIRE
ENCOMPASSING, COMPLEMENTARY, AND
INCREMENTAL TECHNOLOGICAL CHANGES IN THE
LITHOTRIPSY INDUSTRY
}

ANURADHA NAGARAJAN AND WILL MITCHELL*

University of Michigan Business School, Ann Arbor, Michigan, U.S.A.

\begin{abstract}
This study links theories concerning methods that firms use to acquire technology with theories concerning types of technological change. We place particular emphasis on interorganizational relationships. We predict that firms will often acquire know-how needed for encompassing technological change through equity-based arrangements with other organizations, complementary technological changes through nonequity interorganizational arrangements, and incremental changes through internal $R \& D$. Our theory draws on perspectives that emphasize the need to develop new competencies within a business organization and to protect the value of existing competencies. Our empirical analysis examines methods of technology acquisition that firms have used in the commercialization of medical lithotripters, which are devices that fragment stones in the kidney and gall bladder. The analysis contributes to a better understanding of how technology acquisition methods vary with the manner in which technological change relates to a firm's existing capabilities. The study also helps develop our understanding of the evolutionary processes by which capabilities diffuse through an industry. (C) 1998 John Wiley \& Sons, Ltd.
\end{abstract}

Firms often must acquire new know-how as technology changes in an industry. Past research identifies different ways that firms acquire new knowhow when technological change affects their businesses, including internal development and acquisition from other firms (e.g., Teece, 1986; Mitchell and Singh, 1992; Pisano, 1990; Williamson, 1991). In parallel, other research describes different types of technological change (e.g., Abernathy and Utterback, 1978; Abernathy and Clark, 1985; Tushman and Anderson, 1986; Henderson and Clark, 1990; Mitchell, 1991). Although the research streams relate to each other, analysts often do not develop the link between them.

This paper shows that internal and interorgani-

Key words: technological change; internal and external know-how acquisition; firm capabilities

* Correspondence to: Will Mitchell, University of Michigan Business School, 701 Tappan Street, Ann Arbor, MI 481091234, U.S.A. zational methods of acquiring know-how vary with the type of technological change. We define technological change as either encompassing, complementary, or incremental, where the categories differ in the degree and the focus of a technological change. We argue that the different types of change will tend to have different effects on firms' existing capabilities. We then predict that firms will often acquire know-how needed for encompassing technological change through equity-based interorganizational relationships, complementary technological changes through nonequity interorganizational relationships, and incremental changes through internal R\&D. A study of 44 cases of technological change that have affected medical lithotripters between 1989 and 1991 supports our predictions. The analysis contributes to a better understanding of how internal development and interorganizational technology acquisition methods vary with the manner in which technological change affects a firm's 
existing capabilities. In turn, the study helps develop our understanding of the evolutionary processes by which capabilities diffuse through an industry.

\section{BACKGROUND AND PREDICTIONS}

\section{Methods of acquiring know-how when technology changes}

Technology is the ability to create products, processes, and services (Friar and Horwitch, 1985). This definition embraces physical assets and nonphysical knowledge, and views technology as systems of activities as well as individual products and processes. Changing an organization's technology involves adjusting the assets, knowledge, and techniques that the organization uses to convert inputs to outputs (Rosenberg, 1972; Tushman and Anderson, 1986). First-mover advantages in capturing key resources and learning curve benefits create incentives for investing in technological adjustment (Schumpeter, 1934; Lieberman and Montgomery, 1988). Firms can carry out such technological adjustments through internal R\&D or by forming relationships with other organizations. External relationships include equitybased associations, such as joint ventures and direct investments, and nonequity associations, such as technology licensing, technology exchanges, testing agreements, technology sharing agreements, and research contracts.

An extensive literature discusses many sources of advantages for internal R\&D over external arrangements for adjusting technology. Two basic types of the advantages of internal $R \& D$ are at the core of the discussions: mitigating risks of opportunistic behavior and building on tacit organizational routines. In part, internal $R \& D$ protects a firm from opportunistic behavior by a partner in an external research relationship, including both reducing inadvertent leakage of proprietary information to a partner and guarding against active opportunism by a partner (Williamson, 1975; Teece, 1986, 1988; Pisano, 1990). Moreover, and often more importantly than issues stemming from opportunism, technology development typically involves the communication of tacit knowledge. The members of a firm often have a common code of communication for discussing tacit knowledge and developing new capabilities (Penrose, 1958;
Arrow, 1974; Nelson and Winter, 1977; Winter, 1987). Such codes often intertwine in the form of cumulative tacit organizational routines that span external organizational boundaries only with difficulty (Cyert and March, 1963; Nelson and Winter, 1982). By contrast, people working within a single business unit often can exchange and develop tacit information owing to their common understanding of the business's routines (Cohen and Levinthal, 1990), while people working within a multiproduct firm may be able to build on a common technology and develop applications in different product areas (Nelson, 1959; Argyres, 1996). Thus, internal R\&D offers the potential to protect existing competencies and to develop new competencies within a business organization.

The strength of internal R\&D is also a limitation. It is often costly and difficult for businesses to develop capabilities that are new to a firm's existing internal R\&D repertoire. Cost issues arise because the irreversible commitments required of the firm under conditions of significant uncertainty may impede the investment in internal R\&D that requires new assets (Mueller and Tilton, 1969; Ghemawat, 1991). In addition to cost issues, internal development encounters difficulties that arise owing to forces both outside and within a focal business. Externally, institutional forces may limit a firm's investment paths by constraining its behavior within accepted activities and arenas (Scott, 1987). Within the business organization, organizational inertia may limit the expansion of the firm's existing bundle of routines and inhibit the firm's ability to develop technological competency in areas beyond the firm's local search area (Cyert and March, 1963; Nelson and Winter, 1982). For reasons stemming from both cost and difficulty, therefore, internal $\mathrm{R} \& \mathrm{D}$ is likely to be most effective when the new capabilities being developed relate to the organization's existing set of capabilities.

Firms often use external know-how acquisition methods when faced with limits and constraints on internal research, where external methods sometimes involve equity holdings and sometimes taking nonequity approaches. Using external sources allows a firm to acquire technology that is outside its current capabilities (Singh and Mitchell, 1996). Equity-based relationships allow greater control of technology acquisition than do 
nonequity approaches, but also require longerterm financial and managerial commitment to the other party.

We expect that different types of technological change will tend to have different relationships with firms' existing capabilities and, therefore, influence the choice between internal development and external acquisition of new know-how. The following section describes different types of technological change and develops our arguments concerning how they will affect the methods firms use to acquire new know-how.

\section{Encompassing, complementary, and incremental technological change}

We distinguish among three types of change within a technological system: encompassing, complementary, and incremental changes. The types of change vary on two dimensions: first, the degree of change and, second, whether the changes tend to focus on core or complementary activities of the firm. Encompassing changes involve radical alteration of core activities, regardless of the degree to which the changes also affect complementary activities. Complementary changes involve radical alteration of complementary activities that do not also involve radical alteration of core activities. Incremental changes involve incremental adjustments to core or complementary activities. The two dimensions, of radical vs. incremental innovations and of core vs. complementary activities, are common to many perspectives in the technology literature.

Many analyses view technological change as a process in which incremental changes follow radical advances in technology (Sahal, 1985). Radical innovations are changes that draw on a different set of engineering and scientific principles and significantly alter the set of competencies required for success and survival (Jewkes, Sawers, and Stillerman, 1958; Tilton, 1971; Abernathy and Utterback, 1978). These innovations alter the competitive dynamics of the industry significantly. Radical innovations often destroy capabilities, both in the ability to create goods and services and in the ability to sell them in a market (Mitchell and Singh, 1993; Christensen and Bower, 1996). Incremental innovations are improvements, refinements, minor modifications, and extensions of core or complementary product and process technology that enhance the utility or reduce the cost of an existing product (Utterback and Abernathy, 1975; Abernathy and Clark, 1985). Incremental innovations tend to build on existing capabilities of firms and exploit the potential of established designs (Argyres, 1996).

Like the distinction between radical and incremental changes, the distinction between core and complementary activities exists within many strands in the technology literature. Authors have used several terms to describe the general concepts. Thompson (1967) distinguished between core activities at the focus of a firm's attention and peripheral activities that extend beyond the boundaries of the firm but affect the firm's activities. In parallel, Richardson (1972) distinguished between similar and complementary activities. Richardson defined similar activities as the bundle of routines that a firm is most familiar with and monitors most closely, and defined complementary activities as those activities essential to the overall commercialization process that do not fall within the specialized set of a firm's routines. Cleland and Bursic (1992) distinguished between core technology that firms require to make a product or service and complementary technology that supports the product or the service. Similarly, Henderson and Clark (1990) distinguished between core product technologies and complementary technologies, while also identifying linkages among components as key foci of change. Argyres (1996), meanwhile, distinguishes between changes that deepen a firm's existing knowledge and changes that broaden a firm's existing capabilities.

Drawing on the prior research, we use the concepts of core and complementary activities for our study. Core activities are the set of routines involving physical assets, knowledge, and competencies that are intrinsic to the engineering and manufacturing of a product. Complementary activities are the set of routines involving physical assets, knowledge and competencies that contribute to the production of or enhance the commercial utility of a product. In some cases, there will be ambiguity between core and complementary activities. Indeed, the existence of indistinct gray areas helps explain why similar firms respond differently in similar environments, as managerial perceptions may differ concerning what is core and what is complementary, or seemingly minor firm-level differences may underlie substantial 
differences in what actually are core and complementary activities at different firms. Nonetheless, the concepts of core and complementary activities are sufficiently distinct that they have both empirical and conceptual value.

The intersection of the two dimensions of technological change, that is, of radical or incremental type of change with core or complementary locus of change, produces our basic typology of encompassing, complementary, and incremental change. As we noted above, encompassing changes involve radical alteration of core activities, regardless of the degree to which the changes also affect complementary activities. Complementary changes involve radical alteration of complementary activities that do not also involve radical alteration of core activities. Incremental changes involve incremental adjustments to core or complementary activities. Our three-part typology is similar to Henderson and Clark's (1990) fourpart framework of technological changes, which distinguishes between incremental, modular, architectural, and radical innovation. Radical and modular innovation in the Henderson and Clark framework both involve changes to core technology and, therefore, are equivalent to encompassing change in our typology. Architectural and incremental innovation in the Henderson and Clark framework may be either complementary or incremental innovation in our typology, depending on whether complementary technology changes. The primary advantage of our three-part approach is that it incorporates complementary technology and is empirically tractable in situations involving multiple firms and innovations.

Some examples may help clarify the concepts of encompassing, complementary, and incremental change. As an encompassing change, consider Henderson and Clark's (1990) example of the central air conditioner as the replacement for the electric fan. Both products target similar customers to fulfill similar needs but the airconditioning unit uses different inputs, different scientific principles, and different distribution channels when compared to the electric fan. In an earlier period, electrical fans embodied encompassing changes with respect to fans powered by manual or other sources. In our terms, in both cases the core activities of firms producing the fans have undergone encompassing change. Complementary technological change occurs when the core activities required remain basically unchanged but the complementary activities undergo radical change. Such cases may involve the processes used by the buyers in their commercialization of the product and by the firms that provide components and capital equipment for the production process. Tire technology, for instance, complements the core technology of a motor vehicle. The move to radial tires from bias ply did not directly affect core automobile technology but had significant impacts on automotive manufacturers by affecting the design and manufacture of suspension, brake, and steering systems. Incremental technological change occurs when incremental innovations affect core or component activities. Incremental changes tend to improve the product or process without radically altering their paradigms. For instance, Sony offered $8 \mathrm{~mm}$ Camcorder versions TR31, TR71, TR81 and TR101 during the early 1990s. All camcorders have the same broad functionalities but each version has some aspect that differs from the previous model.

\section{Hypotheses}

Encompassing, complementary, and incremental changes often have substantially different effects on a firm's existing knowledge and, in turn, on the methods that firms use to acquire new knowledge. The following hypotheses address the methods that firms will tend to use to acquire know-how needed for different types of change. We begin with encompassing changes, next discuss complementary changes, and then turn to incremental changes.

Encompassing technological changes substantially alter the principles by which the product achieves its functionality (Dewar and Dutton, 1986). New technology that is radically different from the previous technology renders many resources and competencies of existing businesses obsolete, so that the businesses must acquire new capabilities if they wish to continue to operate (Cooper and Schendel, 1976; Abernathy and Utterback, 1978; Ettlie, Bridges, and O'Keefe, 1984; Abernathy and Clark, 1985; Tushman and Anderson, 1986). Encompassing changes directly affect the core technology that a firm employs, so that the impact of such obsolescence is often extreme and may threaten business survival.

We expect that firms will often form interorganizational relationships in order to acquire the 
know-how needed for encompassing technological change. Many authors have argued that firms have limited repertoires of key routines (e.g., Cyert and March, 1963; Rumelt, 1974; Nelson and Winter, 1982; Prahalad and Bettis, 1987; Dosi, 1988; Ramanujam and Varadarajan, 1989). Firms faced with encompassing change often require new routines that are outside the realm of their internal R\&D capabilities. The firms must acquire knowledge of new scientific principles, manufacturing processes, and marketing approaches. Technology development within the firm is often both slow and expensive under these conditions, because the expertise developed by the firm will often not be relevant to the change. Acquiring firms with the requisite technology is an alternative means of acquiring resources, but several factors limit acquisitions as alternatives to interorganizational relationships. First, the acquiring firm must possess the financial and management resources needed for acquisition. Second, potential target firms may have an assortment of resources, including many capabilities that the acquiring firm does not need. Third, technological change may occur more rapidly than firms can identify acquisition targets and negotiate acquisitions. Fourth, institutional reasons such as external regulatory barriers may preclude acquisitions. Interorganizational relationships provide the particular external capability that the firm requires, without encountering the financial, managerial, temporal, and institutional barriers to acquisition.

Many analysts argue that interorganizational relationships often provide viable alternatives to internal development and firm acquisition as a means of acquiring new skills, particularly in dynamic environments in which firms lack time needed to develop internal skills or identify and negotiate with potential acquisition targets (e.g., Richardson, 1972; Mariti and Smiley, 1983; Jorde and Teece, 1990; Williamson, 1991; Martin, Swaminathan, and Mitchell, 1998). From the point of view of potential interorganizational partners, industry incumbents will sometimes be willing to ally together to address the uncertainties and expense of encompassing changes. Moreover, encompassing technological change often provides the foundation for entry to an industry by start-up firms and by established companies that undertake diversifying entry from outside the industry. Entrants often possess valuable product and process know-how, but lack industry-specific knowledge and financial resources required for independent entry and often are willing to become partners of incumbent firms (Mitchell and Singh, 1992). The growing recognition of these benefits has given rise to the idea of interfirm virtual corporations as a means for businesses to adapt in changing environments (Byrne, 1993). Although there are substantial limits to interorganizational adaptability (Miles and Snow, 1992; Singh and Mitchell, 1996), such interfirm relationships play key roles in modern markets.

We expect that firms will tend to use equitybased interorganizational relationships for encompassing technological changes. Because the encompassing change will often diminish the value of a firm's capabilities, the firm must focus on acquiring new technology with a view to rebuilding its core activities. Given the tacit nature of much of the knowledge that the firm needs to acquire and the high stakes that the firm must attach to the outcome of this decision, equity-based relationships provide a framework for both learning about new technology and for protecting technology acquisition (Nueno and Oosterveld, 1988; Klein, 1988; Pisano and Teece, 1989; Mitchell, 1991). On the learning dimension, the organization must learn about engineering and technological principles that are new to the firm, which often requires close communication and interaction with another firm. On the protection dimension, equity-based relationships usually involve administrative hierarchies for monitoring and control and thereby offer a guard against opportunistic behavior by a partner (Williamson, 1985; Pisano, 1990; Jorde and Teece, 1990).

Hypothesis 1: Firms will tend to use equitybased interorganizational relationships to acquire know-how when technological change is encompassing.

Complementary changes have different influences on a firm's capabilities than do encompassing changes. Complementary technological changes sometimes trigger adjustments in a firm's core routines. Taking the tire example used earlier, the car manufacturer must accommodate the new tire specifications into the automotive design and adjust to the new weight and friction characteristics of the tires. The changes have less drastic effects on a firm's resource base than do 
encompassing changes, however, and in some cases the core activities will remain unchanged even when a radical change takes place in the complementary technology, so that most of the firm's capabilities will remain intact and relevant. Nonetheless, although the changes may appear to be minor, a firm must manage the change in the complementary technology carefully, for at least two reasons. First, the firm must adjust to the new technology in order to maintain competitive positioning. Second, changes in complementary technologies may provide a window of opportunity for the firm to improve the core technology of the product. Therefore, firms often benefit by encouraging, moderating, and exploiting complementary technological change.

We expect nonequity relationships to be more common than internal $\mathrm{R} \& \mathrm{D}$ and equity-based relationships in cases of complementary technological change. Internal R\&D is often ill equipped to develop complementary technologies because the firm's capabilities often focus on the core technologies and the activities defined by the core technological system. Equity-based associations, meanwhile, may require substantial financial and managerial commitments that firms can not reverse easily. Complementary technologies, while enhancing the core product functionality, often draw upon different principles and capabilities. The extent to which the complementary technologies apply technologies that are unrelated to the core product's technology determines the potential for economies of scope (Teece, 1980). Unless there are substantial transactions cost advantages to internalizing the development of complementary technologies and potential for achieving economies of scope, firms would tend to use nonequity relationships when faced with complementary technological change. Nonequity relationships allow the firms to monitor technological advance that could enhance the product's effective utilization while retaining the option of soliciting other sources of technology. From the point of view of a provider of complementary technology, a nonequity relationship can add credibility to the innovation especially if the firm is relatively unknown (Shan, 1990; Mitchell, 1991). Further, given the inherent risk and cost of new technology, the close involvement of their technology suppliers is desirable. Such arrangements provide the flexibility required in high-risk situations while allowing firms to exploit any competitive advantage arising out of strategic or efficiency enhancements in complementary activities. Nonequity participation serves as reassurance and commitment by one party to the other.

\section{Hypothesis 2: Firms will tend to use non- equity interorganizational relationships to acquire know-how when technological change is complementary.}

Finally, we expect firms to use internal R\&D for most incremental changes. Although adapting to incremental changes is critically important to firm survival (Banbury and Mitchell, 1995), incremental changes usually do not drastically alter the competencies required by firms in the core and support industries. Instead, the changes tend to reinforce the competitive positions of firms, because they build on their core competencies (Abernathy and Clark, 1985) or they are competence enhancing (Tushman and Anderson, 1986). Because these innovations build on existing architectural and component knowledge, firms compete among themselves to innovate incrementally so as to obtain temporary competitive advantage. Firms use incremental innovations to capture transient market or cost advantages, as well as to build on their existing knowledge and skill base to attain competitive advantages (Cohen and Levinthal, 1990). Firms tend to use their existing competence base to lead or respond to incremental change, and often are able to rely on internal $R \& D$ to develop specific innovations that enhance a firm's particular capabilities.

\section{Hypothesis 3: Firms will tend to use internal $R \& D$ to acquire know-how when technological change is incremental.}

In summary, we expect that firms will often acquire know-how needed for encompassing technological change through equity-based interorganizational relationships, complementary technological changes through nonequity relationships, and incremental changes through internal $\mathrm{R} \& \mathrm{D}$. We believe that the predictions concerning technology acquisition via interfirm relationships will hold in many settings. Relevant settings include industries in which there are many small firms that lack the resources to undertake frequent acquisitions, cases in which technology changes more rapidly than firms can nego- 
tiate business acquisition agreements, and in cases when the capabilities required for encompassing and complementary changes exist within businesses and other organizations that have many capabilities beyond those that are the target of the particular innovation. These conditions exist within the lithotripsy industry, which is the empirical setting for this study, and in many other industrial sectors.

\section{NEW TECHNOLOGY IN THE MEDICAL LITHOTRIPSY INDUSTRY}

The lithotripter is a medical device that uses electrohydraulically generated shock waves to disintegrate kidney stones into tiny fragments that easily pass in urine. Technological innovation in the medical industry has had dramatic impact on surgical therapies used for kidney stones. Prior to the introduction of the lithotripter, removal of kidney stones involved painful surgery and several days in hospital. The development of extracorporeal shock wave lithotripsy (ESWL) has successfully changed kidney stone therapy. According to published reports, ESWL is now the preferred treatment for approximately 80-85 percent of kidney stones (Lingeman, 1996). The entire procedure lasts less than an hour and most patients feel little discomfort. A collaborative effort of Dornier Medical Systems, Inc. and the Urology Department of Ludwig Maximillians University of Munich required 6 years of research and investigation before the commercialization of the first lithotripter in 1983 (Coleman, Saunders, and Palfrey, 1987). The Dornier lithotripter received FDA approval for sale in the United States in December 1984. The rapid clinical acceptance of ESWL sparked other equipment manufacturers to design and test renal lithotripters that differ from the original Dornier system (Gallivan, 1986). Entrants to the worldwide lithotripsy industry include a wide range of businesses from the United States, several European countries, Japan, and Israel, including entrepreneurial start-up firms, established medical device manufacturers, and diversifying entrants from outside the medical sector.

Many encompassing, complementary, and incremental technological changes occurred within the lithotripsy industry between 1989 and 1991. Some encompassing innovations use laser technologies as alternatives to the ultrasound technology used as the core scientific basis in the original Dornier lithotripter. Examples include the Coumadin green laser fiber lithotripter, pulsedyed laser lithotripter, and Pulsolith. Laser-based approaches such as pulse-dyed laser lithotripsy proved to be an effective technique in patients with difficult bile duct stones according to researchers in Germany (Brambs et al., 1996). These procedures are less invasive, less painful, and less expensive than the initial product based on ultrasound technology. Other encompassing technological changes include the electromechanical impactor and the echo locator. The development of the electrohydraulic lithotripsy probes was a complementary technological innovation that affected the component linkages of the product but left the core concepts of the lithotripter intact. According to a study conducted at the Washington University School of Medicine, the development of the $1.9 \mathrm{~F}$ electrohydraulic probes provides the urologist with a safe, highly effective, and inexpensive method for performing lithotripsy and is the only form of lithotripsy sufficiently malleable to allow routine access for the treatment of lower pole renal calculi (Elashry et al., 1996). Other complementary innovations in the lithotripsy industry include the mobile lithotripter and the catheter acoustic transponder. Incremental changes include modifications to the lithotripter that allow biliary procedures as well as renal applications. Our goal is to determine whether firms used systematically different methods to acquire know-how needed to produce lithotripters that incorporated encompassing, complementary, and incremental technological changes.

We drew the sample for this study from an extensive archival study of published sources and a mailed survey to lithotripter manufacturers. We reviewed all references to 'lithotripsy' or 'lithotripters' in the imaging industry newsletter, $S C A N$, plus the Nexis-Lexis, ABI Inform, and InfoTrac electronic data bases. We searched these sources for references relating to product innovations and for information concerning how firms acquired know-how required for the innovations. We classified the acquisition methods as equitybased relationships, nonequity relationships, and internal $R \& D$ based on the information in the published sources. The initial data set for the analysis included 25 product innovations between 
1989 and late 1991, totaling 63 cases of knowhow acquisition. The cases involved 24 companies, including nine lithotripter manufacturers and 15 suppliers.

We mailed a questionnaire listing the innovations to the senior managing executives of the nine lithotripter manufacturers, requesting their opinion on whether the innovation affected the core concepts or component systems of the lithotripter. We received responses from three of the nine manufacturers, two of which we could use for the study. (The third response simply noted an interest in our study.) The two-firm response somewhat conditions the interpretations of the study's results, as one must be cautious concerning the reliability of the classifications of technological changes. Nonetheless, there was substantial agreement about how the changes affected core and component lithotripsy systems, both in the responses, as we discuss below, and in written reports of the changes. We believe that the combination of archival and survey research provides a solid base for the study.

The responses from the firms allowed us to classify innovations as encompassing, complementary, or incremental. We classed the innovations as encompassing when the respondents stated that an innovation changed the core concepts. We classified the innovation as complementary when the respondents stated that an innovation changed the activities in the component technological system and did not change the core concepts in the lithotripter. We classified the innovation as incremental when the respondents stated that neither the core nor component concepts changed. The classification based on the two responses was the same for 19 (6 encompassing, 10 complementary change, 3 incremental) of the 25 innovations ( $p<0.05$, binomial test for independence). We used the 19 innovations with consistent classification for the analysis, which involved 44 cases of know-how acquisition (9 encompassing, 21 complementary, and 14 incremental). The Appendix lists the innovations.

\section{ANALYSIS}

We first test the hypotheses with univariate statistics based on contingency tables and then estimate binary logit models. The contingency tables provide a clear picture of the cases. The logit analysis provides confidence that the descriptive results are robust.

Table 1 compares the types of technological change with the methods the firms used to acquire know-how. We use log-likelihood ratio $\chi^{2}$ statistics and Fisher's exact test for univariate tests of the hypotheses, based on the contingency table in Table 1. These tests demonstrate the relationship between the type of technological change and the methods that firms used to acquire technology. Log-likelihood ratio $\chi^{2}$ tests of the homogeneity of a contingency table are sometimes misleading when the sample size is small. Therefore, we also calculated Fisher's exact test based on the hypergeometric distribution.

The distribution of observations in Table 1 is consistent with the proposition that the degree and focus of technological change influence the methods firms use to acquire technology. Twentynine of the 44 cases $(66 \%)$ conform to the predicted relationships. Both the $\chi^{2}$ test for homogeneity and Fisher's exact test reject the null hypothesis of no association among the variables. As sensitivity analysis, we excluded the 14 cases of incremental innovations in order to eliminate the possibility that the incremental innovations, which realized the greatest conformity with the predictions, might cause the lack of independence in the results. Therefore, we tested for homogeneity using a $2 \times 3$ cell contingency table containing only the observations relating to the nine encompassing and 21 complementary innovations. The log-likelihood ratio $\chi^{2}$ statistic $\left(\chi^{2}=13.7,2\right.$ d.f.; probability $=0.001)$ and the Fisher's exact test (probability $=0.003$ ) for the restricted sample confirm the conclusion that there is a relationship between the method firms use to acquire technology and the nature of technological change.

\section{Univariate analysis: General support}

The results in Table 1 support each hypothesis. Hypothesis 1 predicted that firms will tend to use equity-based interorganizational relationships to acquire know-how required for encompassing technological change. Of the nine instances of encompassing technological change in the industry, firms used equity participation for six cases $(67 \%)$ and in-house $R \& D$ for three cases. It is noteworthy that there were no nonequity relationships for the encompassing changes, so that the 
Table 1. Case-wise comparison: Types of technological change and methods used to acquire know-how (The cases on the diagonal, reported in italic type face, are consistent with the predictions.)

\begin{tabular}{lccccc}
\hline \multicolumn{4}{c}{ Methods used to acquire technology } \\
\cline { 2 - 5 } $\begin{array}{l}\text { Technological } \\
\text { change }\end{array}$ & $\begin{array}{c}\text { Equity-based } \\
\text { relationships }\end{array}$ & $\begin{array}{c}\text { Nonequity } \\
\text { relationships }\end{array}$ & $\begin{array}{c}\text { Internal } \\
\text { R\&D }\end{array}$ & $\begin{array}{c}\text { Total } \\
\text { cases }\end{array}$ & As predicted \\
\hline Encompassing & 6 & 0 & 3 & 9 & $67 \%$ \\
Complementary & 3 & 12 & 6 & 21 & $57 \%$ \\
Incremental & 1 & 2 & 11 & 14 & $79 \%$ \\
Total cases & 10 & 14 & 20 & 44 & $66 \%$ \\
\hline
\end{tabular}

Log-likelihood ratio $\chi^{2}$ statistic $=23.3$ (4 d.f., probability $\left.<0.001\right)$

Fisher's exact test: probability $<0.001$

entire set of observations in the encompassing technology category involved equity participation, either through internal R\&D or relationships with other firms. This pattern suggests that encompassing technological changes redefine the rules of competition, such that the stakes are high when a firm responds to the change. Therefore, firms are likely to use technology acquisition modes that involve partial or complete ownership in order to achieve effective monitoring and control when they acquire technology needed for encompassing changes.

Table 1 provides moderate support for Hypothesis 2, which predicted that nonequity interorganizational relationships will be common in cases involving complementary technologies. Over half the responses to such changes involved nonequity relationships (12 of 21 cases; 57\%). The widest variation in responses occurred along this seldomresearched area of technological change, as three firms acquired the required know-how to adapt to such change through equity-based relationships and six firms used their in-house R\&D facilities. We discuss implications of this variance later in this section of the paper. At this point, though, we will note that the results show that complementary technological changes are common components of the competitive landscape. The analysis demonstrates the importance of considering the broader context of the product when studying the effect of technological change on firms.

Table 1 provides strong support for Hypothesis 3 , which predicted that firms will tend to use internal development to acquire know-how when technological change is incremental. Consistent with the prediction, 11 of the 14 instances of incremental technological change (79\%) came through in-house R\&D.

\section{Univariate analysis: Nonconforming cases}

We examined the individual cases in our study in order to attempt to understand the variance in the outcomes. Examining the cases that do not adhere to the predictions provides further insight concerning factors that may influence firm behavior. Two factors, industry entry and firm size, appear to be particularly relevant. We first consider the unexpected outcomes for encompassing change, next address complementary change, and then turn to incremental change.

Three of nine cases in Table 1 do not fit the prediction of equity-based relationships for encompassing change, all involving internal R\&D. When we examined the three cases, we found that all involved diversifying entrants that used internal expertise gained from activities in other medical equipment industries to enter the lithotripter industry. The implication of this observation is that internal experience in other industrial sectors provided the entry point to the lithotripter industry, so that the firms did not need relationships with other businesses. Instead, businesses can sometimes obtain new capabilities from other parts of their firms. This outcome follows the interdivisional expertise logic of Nelson (1959) and Argyres (1996).

Table 1 reports the greatest divergence in choice of method of technology acquisition when technological change is complementary, with nine of 21 cases having nonpredicted outcomes. There were three instances of equity-based relationships. All three cases involved small lithotripter manufac- 
turers that received equity investments as well as complementary technology from larger firms. The likely explanation for the result is that the small firms needed the financial resources of equity relationships as well as technical expertise from their partners. The partners, in turn, likely viewed the equity investment as a form of option on the results of the smaller firms' efforts. There were six cases in which firms used internal $R \& D$ to acquire complementary know-how. Five of the six cases involved existing lithotripter manufacturers that possessed sufficient expertise to adapt to the particular complementary changes. As in the encompassing technology exceptions that we described in the previous paragraph, the existence of needed skills inside the companies obviated the need for external relationships for these firms. It is notable that the firms used all three methods of technology acquisition to acquire complementary know-how. Future studies could fruitfully examine interorganizational relationships in the context of complementary technological change in finer detail. Nonetheless, despite the variation, a majority of the cases were consistent with the predicted relationship between complementary technological change and nonequity methods of technology acquisition. Thus, although there will be substantial variation owing to firm-level differences and other factors, the general tendencies appear to hold.

Three of 14 cases in Table 1 did not conform to the expected use of internal R\&D when technological change was incremental. One case involved an equity-based relationship and two cases involved nonequity relationships. Small firms created two of the three relationships, suggesting that resource scarcity may have been a motivation for the external relationships. The third case involved a nonequity research consortium of eight firms. The use of the consortium for incremental technological change might indicate that the firms were learning about new capabilities before making commitments to more substantial projects.

\section{Multivariate analysis}

In addition to the contingency table analysis, we also estimated binary logit models of firm-level technology adoption methods in order to control for the potentially confounding effect of business size and industry entry. The binary logit method is appropriate for assessing the effects of categorical variables on a dichotomous response variable, providing a categorical response analog to regression models for continuous response variables. We estimated binary logit models of the effect of technological change on each method of technology adoption. At the firm level, the 44 cases of technology adoption involved 59 incidents, because several cases involved relationships between two lithotripter manufacturers. We omitted the case that involved the nonequity research consortium because such consortia are beyond the scope of the study. Thus, the firmlevel data set for the binary logit models consisted of 51 observations, including 14 instances of equity-based relationships, 17 cases of nonequity relationships, and 20 cases of internal R\&D. Table 2 shows the firm-level cross-tabulation of the method of technology acquisition with the nature of technological change. As in the casewise comparison of Table 1, the firm-level results in Table 2 are consistent with the three hypotheses.

We analyzed three binary logit models to verify the interpretation of the contingency tables. Each logit model had one method of technology acquisition as the dependent variable (Equity-based relationships, Nonequity relationships, and Internal R\&D). The explanatory variables included the three types of technological change (Encompassing change, Complementary change, and Incremental change), whether the firm was entering the lithotripsy industry when it acquired the know-how (Industry entrant), and the log of corporate sales (Firm size). As we noted above, our examination of the data suggested that industry entry and firm size might affect acquisition methods. Previous research suggests that size sometimes affects firm behavior (Scherer, 1980), although the direction of the effect is ambiguous. Larger firms may have greater resources at their command and therefore are better able to undertake internal $\mathrm{R} \& \mathrm{D}$, but large firms often have substantial organizational inertia that may inhibit internal R\&D. We used corporate sales in the year prior to the year in which the firms announced the technology acquisition. We used the value of corporate sales in its $\log$ form so as to minimize distortion in the results due to particularly large firms. We found similar results for the predicted variables in sensitivity analysis that used untransformed sales, but the models 
Table 2. Firm-level comparison: Types of technological change and methods used to acquire know-how (The cases on the diagonal, reported in italic type face, are consistent with the predictions.)

\begin{tabular}{lccccc}
\hline \multicolumn{4}{c}{ Methods used to acquire technology } & \\
\cline { 2 - 5 } $\begin{array}{l}\text { Technological } \\
\text { change }\end{array}$ & $\begin{array}{c}\text { Equity-based } \\
\text { relationships }\end{array}$ & $\begin{array}{c}\text { Nonequity } \\
\text { relationships }\end{array}$ & $\begin{array}{c}\text { Internal } \\
\text { R\&D }\end{array}$ & $\begin{array}{c}\text { Total } \\
\text { cases }\end{array}$ & As predicted \\
\hline Encompassing & 9 & 0 & 3 & 12 & $75 \%$ \\
Complementary & 4 & 16 & 6 & 26 & $62 \%$ \\
Incremental & 1 & $1 *$ & 11 & 13 & $85 \%$ \\
Total & 14 & 17 & 20 & 51 & $71 \%$ \\
\hline
\end{tabular}

Log-likelihood ratio $\chi^{2}$ statistic $=35.5$ (4 d.f., probability $\left.<0.001\right)$

Fisher's exact test: probability $<0.001$.

*We omitted one Incremental/Nonequity case in the firm-level data because the case was a research consortium involving eight firms.

using log sales achieved somewhat greater overall fit. Table 3 reports descriptive statistics and correlations.

Table 4 shows the results of the binary logit models of firms' responses. All models are statistically significant, based on the log-likelihood $\chi^{2}$ statistics reported at the foot of the table. The logit results support each of the three hypotheses.

To test Hypothesis 1, the first model in Table 3 uses equity-based relationships as the dependent variable. The parameter estimate for encompassing technological change is positive and significant, as predicted.

To test Hypothesis 2, the second model used nonequity relationships as the dependent variable. There were no cases where firms used nonequity relationships to address encompassing technological change. Therefore, there were four explanatory variables in the model, including complementary change, incremental change, firm size, and industry entrant. As predicted, the parameter estimate for complementary technological change is positive and significant.

To test Hypothesis 3, the third model used internal $R \& D$ as the dependent variable. As predicted, the parameter estimate for incremental technological change is positive and significant.

The other influences reported in Table 4 also are interesting. Larger firms are less likely to undertake either equity-based or nonequity interorganizational relationships and marginally more likely to undertake internal $\mathrm{R} \& \mathrm{D}$, although the internal $R \& D$ coefficient is not statistically significant. In addition, industry entrants tend to avoid equity-based relationships. In this study, the latter result likely stems from the high incidence of diversifying entry by established firms, which have less need than start-up companies of the financial resources offered by equity relationships.

We carried out several sensitivity analyses of the data. We obtained similar results for the

Table 3. Summary statistics and product moment correlations

\begin{tabular}{|c|c|c|c|c|c|c|c|c|c|c|c|}
\hline Variable & Mean & S.D. & Range & 1 & 2 & 3 & 4 & 5 & 6 & 7 & 8 \\
\hline 1. Equity-based relationships & 0.27 & 0.45 & $0-1$ & 1 & -0.43 & -0.49 & 0.59 & -0.28 & -0.26 & -0.18 & 0.08 \\
\hline 2. Nonequity relationships & 0.33 & 0.48 & $0-1$ & -0.43 & 1 & -0.57 & -0.39 & 0.61 & -0.32 & 0.10 & 0.19 \\
\hline 3. Internal $R \& D$ & 0.39 & 0.49 & $0-1$ & -0.49 & -0.57 & 1 & -0.16 & -0.34 & 0.54 & 0.07 & -0.26 \\
\hline 4. Encompassing change & 0.24 & 0.43 & $0-1$ & 0.59 & -0.39 & -0.16 & 1 & -0.57 & -0.32 & 0.05 & 0.36 \\
\hline 5. Complementary change & 0.51 & 0.50 & $0-1$ & -0.28 & 0.61 & -0.34 & -0.57 & 1 & -0.60 & 0.00 & -0.02 \\
\hline 6. Incremental change & 0.25 & 0.44 & $0-1$ & -0.26 & -0.32 & 0.54 & -0.32 & -0.60 & 1 & -0.05 & -0.33 \\
\hline 7. Firm size & 4.10 & 2.45 & $0-10.5$ & -0.18 & 0.10 & 0.07 & 0.05 & 0.00 & -0.05 & 1 & -0.10 \\
\hline 8. Industry entrant & 0.51 & 0.50 & $0-1$ & 0.08 & 0.19 & -0.26 & 0.36 & -0.02 & -0.33 & -0.10 & 1 \\
\hline
\end{tabular}


Table 4. Results of binary logit models of firm-level responses (51 cases) (The cases on the diagonal, reported in italic type face, are the predicted relationships.)

\begin{tabular}{lccc}
\hline Independent variables & \multicolumn{2}{c}{ Dependent variable: Method used to acquire technology } \\
\cline { 2 - 4 } & $\begin{array}{c}\text { 1. Equity } \\
\text { based } \\
\text { relationships }\end{array}$ & $\begin{array}{c}\text { 2. Nonequity } \\
\text { relationships }\end{array}$ & $\begin{array}{c}\text { 3. Internal } \\
\text { R\&D }\end{array}$ \\
\hline Encompassing change & $2.720^{* *}$ & & $-1.581^{* *}$ \\
Complementary change & $(1.218)$ & & $(0.930)$ \\
Incremental change & -0.518 & $1.257^{* *}$ & $-1.663^{* *}$ \\
Firm size (log corporate sales) & $(0.808)$ & $(0.619)$ & $(0.771)$ \\
& -1.328 & $-1.810^{*}$ & $1.302^{*}$ \\
Model log-likelihood $\chi^{2}$ & $(1.202)$ & $-0.188^{* *}$ & $(0.917)$ \\
& $-0.340^{* *}$ & $(0.109)$ & 0.108 \\
& $(0.193)$ & $15.87^{* * *}$ & $18.138)$ \\
& $31.52^{* * *}$ & $(3$ d.f. $)$ & $(4$ d.f. $)$ \\
\hline
\end{tabular}

$* p<0.10 ; * * p<0.05 ; * * * p<0.01$ (one-tailed tests; standard errors in parentheses).

predicted effects when we omitted the firm size and industry entrant variables. We also tested for influences of acquisition frequency and acquisition date in sensitivity analyses, finding no systematic patterns of acquisition methods by acquisition year or among firms that participated in more than two cases of know-how acquisition. Therefore, we believe that the reported results are robust.

\section{CONCLUSION}

This research examines the association between types of technological change and the methods that firms use to acquire new know-how. We demonstrate that the firms in our sample of the medical lithotripsy industry tended to use equitybased interorganizational relationships to acquire know-how for encompassing changes, nonequity interorganizational relationships for complementary changes, and internal R\&D for incremental changes. The results provide insight into technology acquisition strategies used to manage technological change.

The results extend the existing literature concerning types of technological change and methods of technology acquisition. Pisano (1990) found that transaction cost factors such as smallnumbers bargaining hazards and firm-level factors such as R\&D experience may motivate tech- nology acquisition from external sources. This research shows that the intrinsic composition of technological change in terms of its degree and focus also affects technology acquisition patterns. The results are consistent with Henderson and Clark's (1990) conclusion that it is necessary to look beyond the core set of activities defined by a product's technology and include complementary activities to better understand the competitive effects of innovation in an industry. The results also are consistent with Mitchell and Singh's (1992) finding that supporting assets play a key role in alliance formation. The frequent formation of interfirm alliances for encompassing and complementary technological changes suggests that firms often use supporting assets in relationships with other firms when confronted by significant technological change. Thus, rather than view a single product-development organization as the central player in the product-development process, our analysis emphasizes that innovation takes place as a series of complementary activities among firms.

The results also highlight new aspects of the process by which interorganizational relationships provide an evolutionary conduit for the diffusion of capabilities through an industry. Drawing on ideas developed by Nelson and Dosi (1993) and Nelson (1995), Singh and Mitchell (1996) argued that interfirm relationships are part of an evolutionary process of industrial change. The main 
elements of such an evolutionary process include sources of new ideas, means by which the ideas diffuse through portions of an industry, barriers to universal diffusion of the ideas, and means by which firms that do not adopt successful new ideas will ultimately fail. This study directly addresses the diffusion element of this evolutionary process, showing that equity and nonequity interorganizational relationships provide common means for firms to obtain new ideas concerning encompassing and complementary technologies. Implications for imperfect diffusion are also implicit in this study, because almost all interorganizational relationships involve only two firms or, at most, a small proportion of the firms in an industry. Thus, new ideas that arise in a single organization or in a small number of organizations will diffuse through only a portion of an industry in a given period, so long as firms require interorganizational contact to monitor and learn about the use of the ideas. Further study could usefully develop our understanding of such evolutionary processes.

Several additional avenues for further research seem fruitful, concerning environmental and firmlevel factors. Investigating how firms respond to exogenous environmental variations within complementary technologies would add valuable insight to the technological challenge confronting firms. Other environmental factors that might influence the nature of the technology association include value added by the complementary activity, the pace of technological change, and technology life cycles. In addition to exogenous environmental factors, firm-level heterogeneity is likely to affect technology acquisition methods. Differences among firms include at least two components, including their technological knowledge and their network positions. A firm's prior technological knowledge will constrain the type and manner of capabilities it seeks to develop (Nelson and Winter, 1982; Teece and Pisano, 1994). Similarly, a firm's experience in dealing with external partners is an integral component of its stock of skills (Harianto and Pennings, 1990). Firms learn how to deal with alliance partners, what to expect from interorganizational interaction, and how best to utilize the alliance to their advantage. Future research could examine how a firm's historical technological and networking experience affects its methods of acquiring technology. It is clear, though, that the man- ner in which firms acquire technology is a mosaic of organizational and interorganizational arrangements.

The study highlights the importance of interorganizational relationships in the process of technological change. Firms in most modern industries must contend with the frequent technological change. The sources of innovation and the capacity to commercialize effectively are the cornerstones of corporate and economic progress. When there is technological change, firms must adapt to the new environment in a manner that limits costs while permitting rapid response to the changing environment. Without some measure of interfirm cooperation and planning, firms will not be able to make many supplementary and complementary investments needed to develop and commercialize new technologies.

\section{ACKNOWLEDGEMENTS}

We greatly appreciate comments and suggestions from two Strategic Management Journal reviewers. We also appreciate suggestions from reviewers for the 1994 meetings of the Academy of Management TIM division, at which we presented an earlier version of this paper.

\section{REFERENCES}

Abernathy, W. J. and K. B. Clark (1985). 'Innovation: Mapping the winds of creative destruction', Research Policy, 14, pp. 3-22.

Abernathy, W. J. and J. G. Utterback (1978). 'Patterns of industrial innovation', Technology Review, 80, pp. 97-107.

Argyres, N. (1996). 'Capabilities, technological diversification and divisionalization', Strategic Management Journal, 17(5), pp. 395-410.

Arrow, K. (1974). The Limits of Organization. W. W. Norton, New York.

Banbury, C. M. and W. Mitchell (1995). 'The effect of introducing important incremental innovations on market share and business survival', Strategic Management Journal, Summer Special Issue, 16, pp. 161-182.

Brambs, H. J., S. H. Duda, A. Rieber, M. Scheulen and C. D. Claussen (1996). 'Treatment of bile duct stones: Value of laser lithotripsy delivered via percutaneous endoscopy', European Radiology, 6, pp. 734-740.

Byrne, J. A. (8 February 1993). 'The virtual corporation', Business Week, No. 3304, pp. 98-103.

Christensen, C. M. and J. L. Bower (1996). 'Customer 
power, strategic investment, and the failure of leading firms', Strategic Management Journal, 17(3), pp. 197-218.

Cleland, D. I. and K. M. Bursic (1992), Strategic Technology Management: Systems for Products and Processes. AMACOM, New York.

Cohen, W. M. and D. Levinthal (1990). 'Absorptive capacity: A new learning perspective on learning and innovation', Administrative Science Quarterly, 35, pp. 128-152.

Coleman, A. J., J. E. Saunders and E. L. H. Palfrey (January/February 1987). 'The destruction of renal calculi by external shock waves: Practical operation and initial results with the Dornier lithotripter', Journal of Medical Engineering and Technology, 11, pp. 4-10.

Cooper, A. C. and D. Schendel (1976). 'Strategic response to technology threats', Business Horizons, 19, pp. 61-69.

Cyert, R. and J. March (1963). A Behavioral Theory of the Firm. Prentice-Hall, Englewood Cliffs, NJ.

Dewar, R. D. and J. E. Dutton (1986). 'The adoption of radical and incremental innovations: An empirical analysis', Management Science, 32, pp. 1422-1433.

Dosi, G. (1988). 'Procedures and microeconomic effects on innovation', Journal of Economic Literature, 26, pp. 1120-1230.

Elashry, O. M., R. B. DiMeglio, S. Y. Nakada, E. M. McDougal and R. V. Clayman (1996). 'Intracorporeal electrohydraulic lithotripsy of ureteral and renal calculi using small caliber (1.9F) electrohydraulic lithotripsy probes', Journal of Urology, 156, pp. 1581- 1585 .

Ettlie, J. E., W. P. Bridges and R. D. O'Keefe (1984). 'Organizational strategy and structural differences for radical vs incremental innovation', Management Science, 30, pp. 692-695.

Friar, J. and M. Horwitch (1985). 'The emergence of technology strategy: A new dimension of strategic management', Technology in Society, 7(2/3), pp. $143-178$.

Gallivan, M. (20 July 1986). 'The race for competing lithotripters heats up', Hospitals, 60, pp. 70-71.

Ghemawat, P. (1991). Commitment. The Dynamic of Strategy. Free Press, New York.

Harianto, F. and J. M. Pennings (1990). 'Technological innovation through interfirm linkages'. In M. W. Lawless and L. R. Gomez-Meijia (eds.), Strategic Management in High Technology Firms. JAI Press, Greenwich, CT, pp. 15-42.

Henderson, R. M. and K. B. Clark (1990). 'Architectural innovation: The reconfiguration of existing product technologies and the failure of established firms', Administrative Science Quarterly, 35, pp. 9-30.

Jewkes, J., D. Sawers and R. Stillerman (1958). The Sources of Invention. Macmillan, London.

Jorde, T. M. and D. J. Teece (1990). 'Innovation and cooperation: Implications for competition and antitrust', Journal of Economic Perspectives, 4, pp. 75-96.

Klein, B. (1988). 'Vertical integration as organizational ownership: The Fisher Body-General Motors relationship revisited', Journal of Law, Economics and Organization, 4, pp. 199-212.

Lieberman, M. B. and D. B. Montgomery (1988). 'First-mover advantages', Strategic Management Journal, Summer Special Issue, 9, pp. 41-58.

Lingeman, J. E. (1996). 'Lithotripsy and surgery', Seminar on Nephrology, 16, pp. 487-498.

Mariti, P. and R. H. Smiley (1983). 'Co-operative agreements and the organization of industry', Journal of Industrial Economics, 31(4), pp. 437-451.

Martin, X., A. Swaminathan and W. Mitchell (1998). 'Organizational evolution in an interorganizational environment: Vertical, competitor, and communitylevel influences on supplier expansion to foreign markets', Administrative Science Quarterly, forthcoming.

Miles, R. E. and C. C. Snow (1992). 'Causes of failure in network organizations', California Management Review, 34(4), pp. 53-72.

Mitchell, W. (1991). 'Probability and timing of expansion by industry incumbents following evolutionary major product innovation'. In P. Shrivastava, A. Huff and J. Dutton (eds.), Advances in Strategic Management, Vol. 7. JAI Press, Greenwich, CT, pp. 43-60.

Mitchell, W. and K. Singh (1992). 'Incumbents' use of preentry alliances before expansion into new technical subfields of an industry', Journal of Economics, Behavior and Organization, 18(3), pp. 347-372.

Mitchell, W. and K. Singh (1993). 'Death of the lethargic: Effects of expansion into new technical subfields of an industry on performance in a firm's base business', Organization Science, 4(2), pp. $152-180$.

Mueller, D. C. and J. E. Tilton (1969). 'R\&D cost as a barrier to entry', Canadian Journal of Economics, 2, pp. 570-579.

Nelson, R. R. (1959). 'The simple economics of basic scientific research', Quarterly Journal of Economics, 74, pp. 297-306.

Nelson, R. R. (1995). 'Recent evolutionary theorizing about economic change', Journal of Economic Literature, 33, pp. 48-90.

Nelson, R. R. and G. Dosi (1993). 'Evolutionary theories in economics: Assessment and prospects', working paper WP-93-064, International Institute for Applied Systems Analysis, A-2361, Laxenburg, Austria.

Nelson, R. R. and S. G. Winter (1977). 'In search of useful theory of innovation', Research Policy, 6, pp. 36-76.

Nelson, R. R. and S. G. Winter (1982). An Evolutionary Theory of Economic Change. Harvard University Press, Cambridge, MA.

Nueno, P. and J. Oosterveld (1988). 'Managing technological alliances', Long Range Planning, 21(3), pp. 11-17.

Penrose, E. T. (1958). Theory of the Growth of the Firm. Wiley, New York.

Pisano, G. P. (1990). 'The R\&D boundaries of the firm: An empirical analysis', Administrative Science Quarterly, 35, pp. 153-176. 
Pisano, G. P. and D. J. Teece (1989). 'Collaborative arrangements and global technology strategy: Some evidence from the telecommunications equipment industry', Research on Technological Innovation, Management and Policy, 4, pp. 227-256.

Prahalad, C. K. and R. P. Bettis (1987). 'The dominant logic: A new linkage between diversity and performance', Strategic Management Journal, 7(6), pp. 485-501.

Ramanujam, V. and P. Varadarajan (1989). 'Research on corporate diversification: A synthesis', Strategic Management Journal, 10(6), pp. 523-551.

Richardson, G. B. (1972). 'The organization of industry', Economic Journal, 82, pp. 833-896.

Rosenberg, N. (1972). Technology and American Economic Growth. Harper \& Row, New York.

Rumelt, R. P. (1974). Strategy, Structure, and Economic Performance. Harvard Business School Press, Boston, MA.

Sahal, D. (1985). 'Technological guideposts and innovation avenues', Research Policy, 14(2), pp. 61-82.

Scherer, F. M. (1980). Industrial Market Structure and Economic Performance (2nd ed.). Rand McNally, Chicago, IL.

Schumpeter, J. A. (1934). The Theory of Economic Development. Harvard University Press, Cambridge, MA.

Scott, W. R. (1987). Organizations: Rational, Natural and Open Systems. Prentice-Hall, Englewood Cliffs, NJ.

Shan, W. (1990). 'An empirical analysis of organizational strategies by entrepreneurial high technology firms', Strategic Management Journal, 11(2), pp. 129-139.

Singh, K. and W. Mitchell (1996). Precarious collaboration: Business survival after partners shut down or form new partnerships', Strategic Management Journal, Summer Special Issue, 17, pp. 95-115.

Teece, D. J. (1980). 'Economies of scope and the scope of the enterprise', Journal of Economic Behavior and Organization, 1, pp. 223-247.

Teece, D. J. (1986). 'Profiting from technological innovation: Implications for integration, collaboration, licensing, and public policy', Research Policy, 15, pp. 285-305.

Teece, D. J. (1988). 'Technological change and the nature of the firm'. In G. Dosi, C. Freeman, R. Nelson, G. Silverberg and C. Soete (eds.), Technical Change and Economic Theory. Pinter, London, pp. 256-281.

Teece, D. J. and G. P. Pisano (1994). 'The dynamic capabilities of firms: An introduction', Industrial and Corporate Change, 3(3), pp. 537-556.

Thompson, J. (1967). Organizations in Action. McGraw-Hill, New York.

Tilton, J. E. (1971). International Diffusion of Technology: The Case of Semiconductors. Brookings Institution, Washington, DC.

Tushman, M. L. and P. Anderson (1986). 'Technological discontinuities and organizational environments', Administrative Science Quarterly, 31, pp. 439-465.

Utterback, J. M. and W. J. Abernathy (1975). 'A dynamic model of product and process innovation', Omega, 3(6), pp. 639-656.
Williamson, O. E. (1975). Markets and Hierarchies. Free Press, New York.

Williamson, O. E. (1985). The Economic Institutions of Capitalism. Free Press, New York.

Williamson, O. E. (1991). 'Comparative economic organization: The analysis of discrete structural alternatives', Administrative Science Quarterly, 36, pp. 269-296.

Winter, S. G. (1987). 'Knowledge and competence as strategic assets'. In D. Teece (ed.), The Competitive Challenge. Harper \& Row, New York, pp. 159-184.

\section{APPENDIX: CATEGORIES OF TECHNOLOGICAL CHANGE AND LITHOTRIPTER INNOVATIONS}

\author{
A. Encompassing innovations \\ 1. Coumadin green laser fiber \\ 2. Electromechanical impactor \\ 3. Pulse-dyed laser \\ 4. Pulsolith \\ 5. Ultrasound imager (Echo locator) \\ 6. Ursodeoxycholic acid
}

B. Complementary innovations

1. Catheter acoustic transponder

2. Electrohydraulic lithoptripsy probe (1.9F)

3. Flashlamp dye laser

4. Lithox system (contact dissolution system)

5. Mobile ESW

6. Mobile lithotripter

7. Modular renal lithotripter

8. ORACLE PTCA catheter

9. Second-generation sonographic piezoelectric lithotripters (Piezolith 2300)

10. Triper XI

C. Incremental innovations

1. Biliary lithotripter

2. Hydrophones

3. Therasonic system

We omitted six innovations that had conflicting survey responses concerning categories of technological change:

1. Diagnostic and therapeutic urological pharmaceuticals

2. Human monoclonal antibodies

3. Laparoscopic cholecystectomy

4. Organic chemical contact dissolution system

5. Percutaneous nephrostolithotomy

6. Urological diagnosis/therapy table 